\title{
Supercritical Fluid Extraction of Oregano (Origanum vulgare) Essentials Oils Show some In Vitro Anti-Inflammatory Effects Based on Modifying Adipokine Secretion and Gene Expression on TNF- $\alpha$-Induced Adipocytes
}

\author{
A. Ocaña-Fuentes \\ Departamento de Química- Física Aplicada, Sección de Ciencias de la Alimentación, \\ Facultad de Ciencias, Universidad Autónoma de Madrid, Madrid, \\ Spain
}

\section{Introduction}

Adipose tissue plays an important role in energy homeostasis and in innate immune system (Bastard et al, 2006, Desruisseaux et al, 2007). Obesity is characterized by excessive accumulation of abdominal fat, which is known to play an important role in development of chronic inflammation, atherosclerosis, increased risk in cardiovascular disorders and diabetes (Rajala and Sherer, 2003). Pro-inflammatory adipokines, TNF- $\alpha$, IL-1 $\beta$ and IL- 6 are secreted by a variety of cell type, including adipocytes (Desruisseaux et al, 2007, Trayhurn and Wood, 2005). In obesity, these adipokines which are up-regulated in adipose tissue producing a chronic activation of the innate immune system (Bastard et al, 2006), exercise a local (TNF- $\alpha$, IL-1 $\beta$ and IL-6 ) and systemic (IL-1 $\beta$ and IL-6) effect.

During inflammation, the mature adipocytes of adipose tissue are responsible for increasing production of pro-inflammatory adipokines (Simons et al., 2005), including tumor necrosis factor (TNF- $\alpha)$, IL-1 $\beta$, IL-6 and leptin and decreasing the anti-inflammatory adipokines, IL10 and adiponectin (Guilherme et al., 2008). That disregulation contributes to obesity and chronic inflammation (Ouchi et al., 2003).

In addition to inflammatory adipokines secretion, adipocytes are also responsible of leptin synthesis. Leptin is a hormone that plays an important role in the regulation of body mass index (BMI) through the effects on appetite and on energetic expenditure as it encourages catabolic pathways versus anabolic pathways through their effects on 5'-AMP-activated protein kinase (AMPK) in muscle and liver (Rajala and Sherer, 2003). Furthermore, leptin can modulate the proliferation and differentiation of lymphoid cells from immune system and can induce the inflammatory response (Desruisseaux et al, 2007). Also, leptin can lead protrombotic states by the stimulation of plaquetary aggregation at the same time that inhibits the coagulation and fibrinolisis showing a pro-atherosclerotic effect (Wu et al., 2006).

Adiponectin is a hormone exclusively synthesized in mature adipocytes. Adiponectin is down-regulated in obesity, diabetes type 2 and coronary diseases. It present antiinflammatory activity, inhibiting the synthesis of TNF-a in adipocytes and in macrophages 
(Wu et al., 2006) through the modulation of NF-k $\beta$ (Desruisseaux et al., 2007). Furthermore, anti-atherosclerotic effects of adiponectin has been described through his up-regulation in a mouse model of atherosclerosis where the formation of atherosclerotic plaques is reduced (Rajala and Sherer, 2003).

Macrophage infiltration has recently been postulated to be a primary stimulus for the inflammatory properties of adipose tissue. Monocyte chemoattractants, which are synthesized and secreted by adipocytes, are thought to mediated in macrophage infiltration and to intensify macrophage expression of TNF-a (Guilherme et al., 2008)).

Oregano is an aromatic plant of the mediterranean flora commonly used for medical purposes (Bukovska et al., 2007, Juhás et al., 2008). It shows antioxidant and antimicrobial activities, such as inhibiting Helicobacter pillory growth. (Chun et al., 2005). It has also been described as anti-inflammatory when used as treatment of colitis in mice (Bukovska et al., 2007). The biological activity of this plant depends on their composition. Oregano contains thymol and carvacrol, two components with antioxidant and antimicrobial activity (Mastelic et al., 2008). Carvacrol also has demonstrated an antiproliferative activity in tumor cells of HeLa (Mastelic et al., 2008). Thymol has also showed beneficial effects on the antioxidant status of the rat brain (Youdim and Deans, 2000). Our group has previously demonstrated the antioxidant activity of subcritical water extraction of nutraceuticals from oregano using in vitro assays (Rodríguez Meizoso et al., 2006).

It has been described that the treatment of colitic mice with essential oils of thyme and oregano decreases levels of proinflammatory cytoquines IL-1 $\beta$, IL-6, GM-CSF and TNFa. But the mechanisms mediating suppressive effects of thyme and oregano oils on colitis are unclear. It has also been described an inhibitory effect of various plant extracts such as Calendula extracts on NF-kB activation (Bukovska et al., 2007).

Supercritical fluid extraction (SFE) with CO2 is a high-pressure technology, considered an attractive method compared to conventional techniques such as steam distillation or Soxhlet extraction because it avoids solute contamination with solvent residues and the degradation of termolabile compounds (Almeida and ferreira 2007). That is why supercritical fluid extraction with $\mathrm{CO} 2$ is in increasing demand to produce high-quality essential oils from plant material with medicinal properties (Mukhopadhyay, 2000).

The aim of this study is to describe the anti-inflammatory effects of Origanum vulgare extracts placed in an in vitro model of inflammation and other chronic diseases related to the inflammatory process, using human mature adipocytes activate with TNF-a (Gonzales and Orlando, 2008).

\section{Material and methods}

\subsection{Reagents}

TNF-a was purchased from R\&D Systems. Preadipocyte Basal Medium, Fetal Bovine Serum (FBS), L-Glutamine, Penicilin, Streptomycin, Preadipocyte Differentiation Medium, insulin, Dexamethasone, Indomethacin, 3-isobutyl-1-methylxanthine and DMEM/Ham's F-12 1:1 were purchase from Lonza, USA.

\subsection{Supercritical fluid extraction (SFE) of plant material}

Dried and cryogenic grinded leaves from oregano (Origanum vulgare) were subjected to supercritical fluid extraction (SFE) with $\mathrm{CO}_{2}$. The supercritical extractions were carried out in a pilot-plant-scale supercritical fluid extractor (Thar Technology, Pittsburgh, PA, USA, 
model SF2000) of $2 \mathrm{~L}$ capacity using pure supercritical $\mathrm{CO}_{2}$ at a pressure of $30 \mathrm{MPa}$ and a temperature of $40{ }^{\circ} \mathrm{C}$. Extracts from oregano were fractionated using a two-cascade depressurized system consisted of two separators (separator 1 and 2). Fractionation conditions were as follows: separator 1 was kept at a constant pressure and temperature of $15 \mathrm{MPa}$ and $40^{\circ} \mathrm{C}$, respectively, whereas separator 2 was maintained at a pressure of $2 \mathrm{MPa}$, and a temperature of $40{ }^{\circ} \mathrm{C}$. Under these conditions two fractions were obtained, oregano S1 and oregano $\mathrm{S} 2$, corresponding to separator 1 and 2, respectively.

\subsection{Analysis of the supercritical extract by GC/MS}

Characterization of the supercritical oregano fractions oregano S1 and oregano S2 was carried out by a GC-2010 (Shimadzu, Japan), equipped with a split/splitless injector, electronic pressure control, AOC-20i auto injector, GCMS-QP2010 Plus mass spectrometer detector, and a GCMS Solution software. The column used was a ZB-5 (Zebron) capillary column, $30 \mathrm{~m} \times 0.32 \mathrm{~mm}$ I.D. and $0.25 \mu \mathrm{m}$ phase thickness. Helium, $99.996 \%$ was used as a carrier gas at a flow of $1 \mathrm{~mL} / \mathrm{min}$. Oven temperature programming was $60{ }^{\circ} \mathrm{C}$ isothermal for $4 \mathrm{~min}$, increased to $64^{\circ} \mathrm{C}$ at $1{ }^{\circ} \mathrm{C} / \mathrm{min}$, then increased to $106{ }^{\circ} \mathrm{C}$ at $2.5^{\circ} \mathrm{C} / \mathrm{min}$. Oven temperature was then increased from $106{ }^{\circ} \mathrm{C}$ to $130{ }^{\circ} \mathrm{C}$ at $1{ }^{\circ} \mathrm{C} / \mathrm{min}$, and then to $200{ }^{\circ} \mathrm{C}$ at 5 ${ }^{\circ} \mathrm{C} / \mathrm{min}$, and then to a final temperature of $250^{\circ} \mathrm{C} / \mathrm{min}$ at $8^{\circ} \mathrm{C} / \mathrm{min}$ which was kept constant for $10 \mathrm{~min}$. Sample injections $(1 \mu \mathrm{L})$ were performed in split mode (1:20). The inlet pressure of the carrier gas was $57.5 \mathrm{KPa}$. Injector temperature was of $250{ }^{\circ} \mathrm{C}$ and MS ion source and interface temperatures were 230 and $280{ }^{\circ} \mathrm{C}$, respectively. The mass spectrometer was used in TIC mode, and samples were scanned from 40 to $500 \mathrm{amu}$. Compounds thymol, carvacrol and linalool were identified by comparison with standard mass spectra obtained in the same conditions and compared with the mass spectra from library Wiley 229. Remaining compounds were identified by comparison with the mass spectra from Wiley 229 library and by their linear retention index.

\subsection{Cell culture}

Human preadipocytes (Lonza, USA) were incubated in Preadipocyte Basal Medium containing 10\% FBS, $2 \mathrm{mM}$ L-Glutamine, 100 units $/ \mathrm{ml}$ penicilin and $100 \mu \mathrm{g} / \mathrm{ml}$ streptomycin at $37^{\circ} \mathrm{C}, 5 \% \mathrm{CO}_{2}$ in a humidified incubator up to $85-90 \%$ of confluence. Cells were induced to differentiate into adipocytes by incubation with Preadipocyte Differentiation Medium containing insulin, dexamethasone, indomethacin and 3-isobutyl-1methylxanthine for 3 days. After this time, the cells adhering to the culture dish and the medium was replaced every 3 days for 15 days. 15 days later, cells are differentiated into adipocytes. Lipid droplets could be visible into the cells. Afterwards, the Adipocyte Differentiation Medium was removed and the cells were starved in DMEM/Ham's F-12 1:1 for $24 \mathrm{~h}$ prior to assay with the plant extracts. Cells were activated with TNF-a $(10 \mathrm{ng} / \mathrm{ml})$ for $6 \mathrm{~h}$ and then treated with the different extract for $24 \mathrm{~h}$. The supernatant of the different cultures were collected and analyzed for secreted adipokines (IL-1 $\beta$, IL-6, IL-10, leptin and adiponectin).

\subsection{Citotoxicity assay}

Extract toxicity was assessed using the mitochondrial-respiration-dependent 3-(4,5dimethylthiazol-2-yl)-2,5-diphenyltetrazolium (MTT) reduction method. Preadipocytes cells were plated in 96 wells plates, differentiated and incubated with different concentrations of 
the oregano extract for $24 \mathrm{~h}$. at $37^{\circ} \mathrm{C}$ in $5 \% \mathrm{CO}_{2}$. After treatment, the cells were washed with PBS and incubated with MTT $1 \mathrm{mg} / \mathrm{ml}$ in PBS for 2 hours at $37^{\circ} \mathrm{C}$ in $5 \% \mathrm{CO} 2$. Afterwards, formazan crystals produced from MTT by the mitochondrial hydrolase, only activate in viable cells, were solubilized in lysis buffer (10 \% SDS in 50\% dimetilformamida $\mathrm{pH}=7$ ) and the absorbance of each well was then read at $540 \mathrm{~nm}$ using a microplate reader (Sunrise Remote, Tecan). The optical density of formazan formed in control cells (without treatment with extract) was taken as $100 \%$ viability.

\subsection{Bioactivity assay}

Oregano extract was dissolved in dimethyl sulfoxide (DMSO; Sigma-Aldrich) to stock concentration of $10 \mathrm{mg} / \mathrm{ml}$ determined as the maximum non-toxic dose to cells in the viability assays. Differenctiated adipocytes cells were placed and differentiated in 24 well plates. After differentiation, the cells were washed with PBS and incubated with the extract diluted in FBS free medium, for 24 at $37^{\circ} \mathrm{C}$ in $5 \% \mathrm{CO} 2$. Afterwards, the supernatant was frozen and RNA from cells was isolated. Aliquots were analyzed to determine secreted adipokines, leptin and adiponectin.

\subsection{Total protein quantification}

The Bradford method was used to determine the total protein content in the supernatant. 5 $\mu \mathrm{l}$ of supernatant was incubated with $250 \mu \mathrm{l}$ of Bradford reagent (Sigma) for $30 \mathrm{~min}$ in the dark at room temperature. The absorbance at 595 was measured and the protein concentration was determined using a standard curve.

\subsection{Enzyme-linked Immuno Sorbent Assay for quantification of cytokines}

The supernatant of the different treatments culture was collected from each samples. The concentrations of IL-6, IL-10, IL-1 $\beta$ were assayed using a ELISA kit from BD Biosciences, and leptin, adiponectin were assayed using a ELISA kits from R\&D Systems. The absorbance read at $450 \mathrm{~nm}$ with $\lambda$ correction at $570 \mathrm{~nm}$ using a microplate reader (Sunrise Remote, Tecan Austria GmbH, Grödig, Austria). Each concentration was determined from the standard curve and expressed as \% of TNF- a activated controls.

\subsection{Total RNA isolation}

Total RNA from adipocytes was isolated using the Trizol® reagent from Invitrogen. 9.000 cells were homogenized in $200 \mu \mathrm{L}$ of Trizol ${ }^{\circledR}$ reagent and, if necessary, stored at $-80{ }^{\circ} \mathrm{C}$. Following homogenization, samples were left at room temperature for 5 minutes. Afterwards, $40 \mu \mathrm{L}$ of chloroform was added and the tubes were vigorously shaken for 15 seconds and left to rest at room temperature for 5 minutes. Tubes were then centrifuged at $12000 \mathrm{~g}, 4^{\circ} \mathrm{C}$ for 15 minutes. The aqueous (upper and colorless) phase was transferred to a new tube. $100 \mu \mathrm{L}$ of isopropyl alcohol was added to the aqueous phase; the tube was then gently mixed and incubated at room temperature for 10 minutes. After incubation, samples were centrifuged at $12000 \mathrm{~g}, 4{ }^{\circ} \mathrm{C}$ for 10 minutes. A gel-like pellet was formed and the isopropyl alcohol removed. The pellet was washed with $200 \mathrm{~mL}$ of $75 \%$ Ethanol in DEPC treated $\mathrm{H}_{2} \mathrm{O}$, and centrifuged at $7600,4{ }^{\circ} \mathrm{C}$ for $5 \mathrm{~min}$. The ethanol was then removed and the pellet left to dry until colorless. Total RNA was then dissolved in $15 \mu \mathrm{L}$ of DEPC $\mathrm{H}_{2} \mathrm{O}$, incubated at $55^{\circ} \mathrm{C}$ for 10 minutes and stored at $-80^{\circ} \mathrm{C}$ for future use. 


\subsection{Gene expression quantification}

IL-1 $\beta$, IL-6, IL-10, and 18sRNA gene expression were quantified using real-time PCR. 10 $\mathrm{ng} / \mu \mathrm{L}$ of total RNA isolated from mature adipocytes cells was used as template for cDNA synthesis using the High Capacity Archive Kit from Applied Biosystems, according to the manufacturer's instructions. Real-time PCR was performed using Taqman Probes (Applied Biosystems) following the manufacturer's recommendations. The Taqman probes used were: Hs99999029_m1 for IL-1 $\beta$, Hs00174131_m1 for IL-6, Hs999999035_m1 for IL-10, Hs00174877_m1 for leptin, Hs00605917_m1 for adiponectin, and Hs99999901_s1 for 18S rRNA. Gene expression levels were then normalized to $18 \mathrm{~S}$ rRNA expression and compared to it.

\subsection{Statistical analysis}

All data were expressed as the mean \pm SEM. For single variable comparisons, Student's ttest was used. For multiple variable comparisons, data were analyzed by one-way analysis of variance (ANOVA) followed by Dunnett's test using SigmaStat statistical software (Windows Version 5.0 Systat Software Inc., Point Richmond, CA, USA). P values lower than 0.05 were considered significant.

\section{Results}

\subsection{Composition of the supercritical oregano fractions}

Two fractions of the Origanum vulgare leaves extract, oregano S1 and oregano S2, were isolated using supercritical fluid extraction with $\mathrm{CO}_{2}$ and their composition was determined

\begin{tabular}{|l|c|c|c|c|}
\hline Compound & $\begin{array}{c}\text { Retention } \\
\text { time (min) }\end{array}$ & R.I. & $\begin{array}{c}\text { \% Area } \\
\text { (Separator 1) }\end{array}$ & $\begin{array}{c}\text { \% Area } \\
\text { (Separator 2) }\end{array}$ \\
\hline Sabinene & 10.20 & 971,00 & n.d. & 1.04 \\
\hline Alpha-terpinene & 12.52 & 1015,00 & n.d. & 0.74 \\
\hline P-cymene & 12.94 & 1023,00 & 7.70 & 1.22 \\
\hline Limonene & 13.19 & 1027,00 & n.d. & 0.47 \\
\hline Gamma-terpinene & 14.93 & 1057,00 & 2.08 & 4.04 \\
\hline Sabinene hydrate <cis> & 15.39 & 1065,00 & 2.46 & 3.75 \\
\hline Sabinene hydrate <trans> & 17.17 & 1096,00 & 45.81 & 46.05 \\
\hline Linalool & 17.35 & 1100,00 & 2.39 & 2.73 \\
\hline 4-terpineol & 21.74 & 1175,00 & 2.30 & 5.44 \\
\hline Alpha-terpineol & 22.52 & 1189,00 & 1.87 & 2.34 \\
\hline N-I & 25.09 & 1231,00 & n.d. & 0.70 \\
\hline Thymyl methyl ether & 25.61 & 1240,00 & 1.03 & 2.11 \\
\hline Sabinene hydrate acetate <trans> & 26.17 & 1250,00 & 1.45 & 0.91 \\
\hline Linalyl acetate & 26.40 & 1254,00 & 1.55 & 1.55 \\
\hline Thymol & 28.65 & 1291,00 & 24.00 & 19.99 \\
\hline Carvacrol & 29.23 & 1300,00 & 8.07 & 7.07 \\
\hline E-caryophyllene & 37.80 & 1412,00 & n.d. & 1.68 \\
\hline
\end{tabular}

Table 1. Composition of the supercritical extracts of oregano (Origanum vulgare L.) obtained in separators 1 and 2. Contribution of each compound to the total chromatographic area. NI: non-identified compound. R.I.: linear retention index. n.d. non-detected. 
by gas chromatography-mass spectrometry (GCMS) (see Table 1). For both fractions, the main compounds present were sabinene hydrate <trans>, thymol and carvacrol. Chemical structures of these compounds are shown in figure 1.

a)

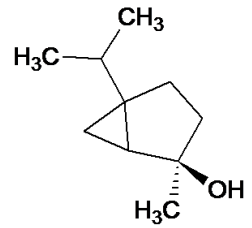<smiles>Cc1ccc(C(C)C)c(O)c1</smiles><smiles>Cc1ccc(C(C)C)cc1O</smiles>

Fig. 1. Chemical structures of the main compounds present in the supercritical extracts of oregano (Origanum vulgare.). a) Sabinene hydrate $<$ trans $>$, b) thymol and c) carvacrol.

\subsection{TNF- $\alpha$ treatment activates protein expression in differentiated adipocytes}

To examine the effects of TNF-a on secretion of adipokines, fully differentiated human adipocytes were treated for different times $(4,6$ y 8 hours) with several concentration of recombinant human TNF-a (Anh et al., 2007). Proteins secreted into the medium were measured by the Bradford assay. These TNF-a treated cells showed an increase in total protein secreted (see Figure 2). Increase in protein secretion was used as indicator for adipocyte activation. The secretion of proteins increased from 4 hours to 8 hours, and the levels were stable for 6 hours at concentration of $10 \mathrm{ng} / \mathrm{ml}$.

\section{Levels of total protein}

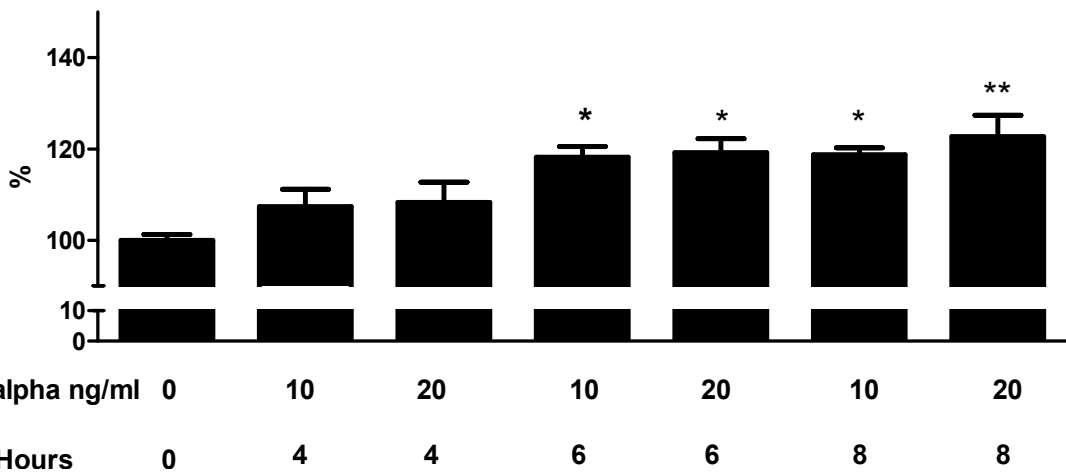

Fig. 2. Levels of total protein in TNF- a induced secretion of human adipocytes. Results are shown as the means \pm SEM of triplicate determinations. Statistic Dunnett's multiple comparison test VS Ctrl - TNF- a signification is represented by * P values less than 0.05 significant ** $\mathrm{P}$ values less than 0.01 very significant and ${ }^{* *} \mathrm{P}$ values less than 0.001 extremely significant. 


\subsection{Oregano hardly shows cytotoxicity in adipocytes}

Prior to examine the effects of oregano on adipokine secretion, we wished to confirm that the extracts were not toxic for this cell. So we incubated adipocytes for several extract concentrations during 24 hours. Figure 3 shows the effects of the oregano extracts in human subcutaneous adipocytes. In both extracts (oregano S1 and oregano S2) there were no significant decreases in cell viability using concentrations lower or equal to $30 \mu \mathrm{g} / \mathrm{ml}$.

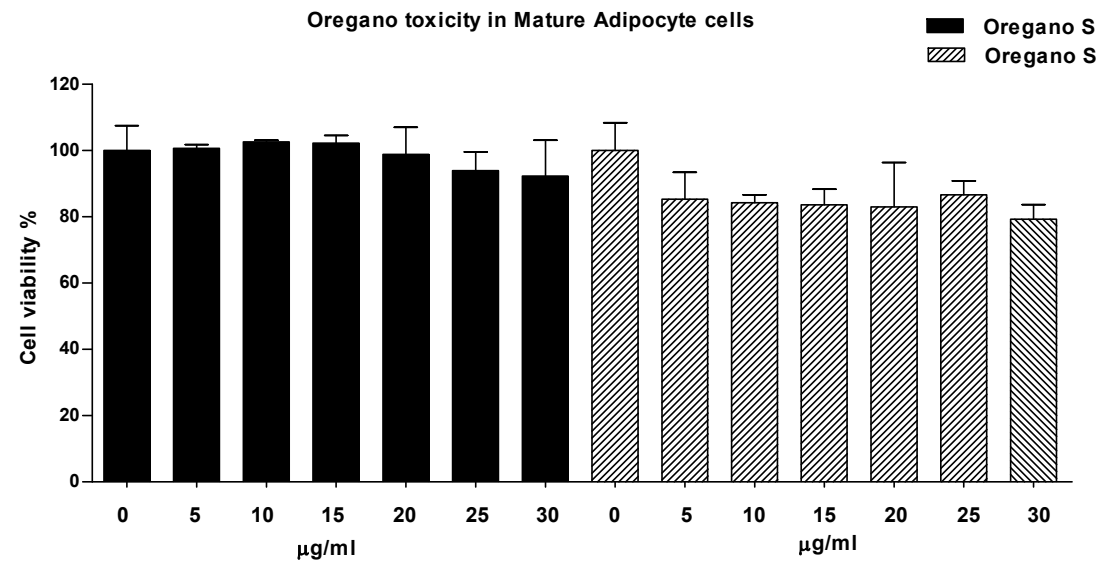

Fig. 3. Effects of oregano on mature adipocytes viability. Cells were treated with increasing concentrations of oregano S1 and S2 (from 0 to $30 \mu \mathrm{g} / \mathrm{ml}$ ), for $24 \mathrm{~h}$. Cell viability was determined by the MTT assay. Values represent the mean \pm SEM of three independent experiments and statistic signification is represented by ** $P$ values less than 0.01 very significant and ${ }^{* * *} P$ values less than 0.001 extremely significant.

\subsection{Effect of oregano extracts on the TNF- $\alpha$-induced secretion of adipokines and their gene expressions}

To investigate whether oregano could have a play in the TNF- a-induced secretion of adipokines by adipocytes, human adipocytes were pre-treated with TNF- $\alpha$ in a concentration

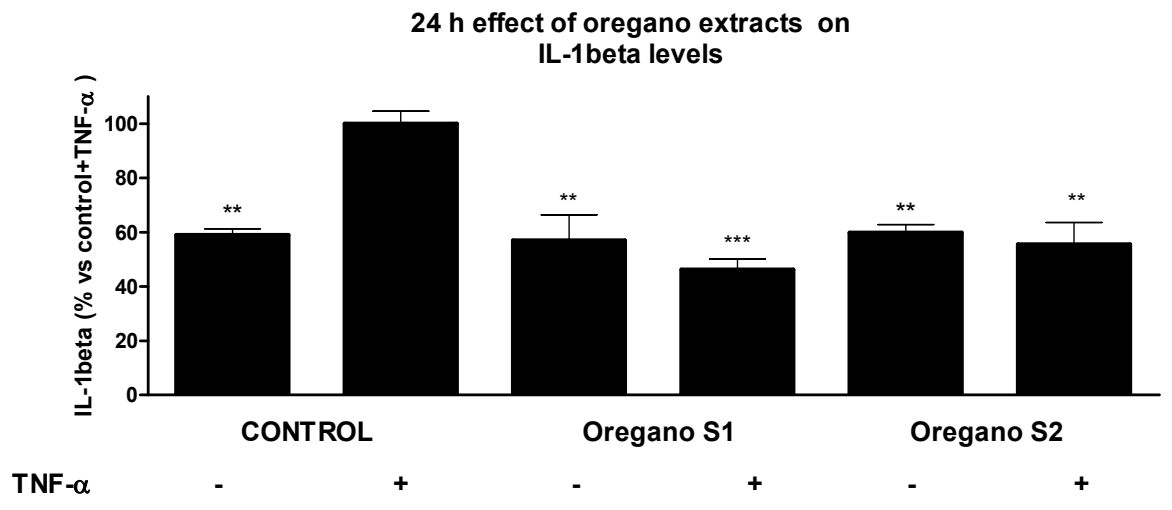

Figure 4A 


\section{$24 \mathrm{~h}$ effect of oregano extracts on \\ IL-6 levels}

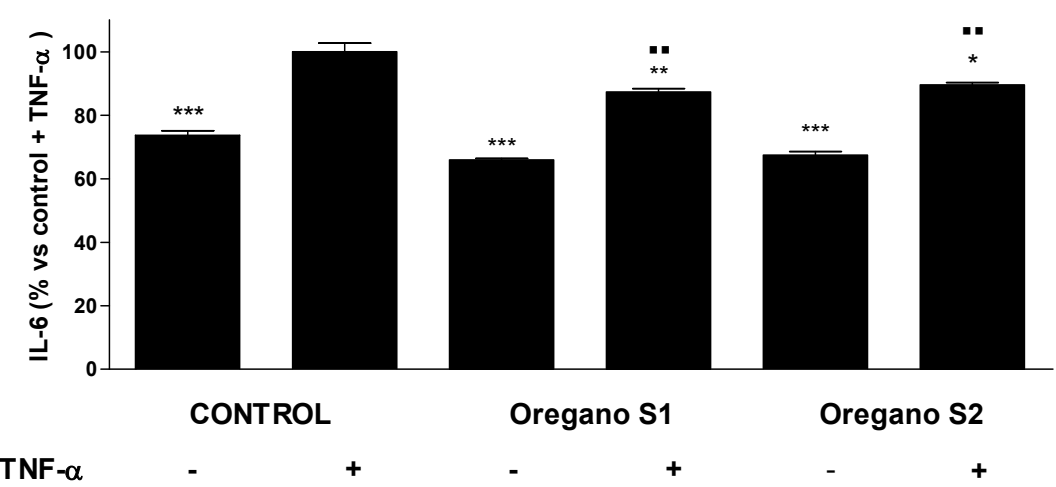

Figure 4B

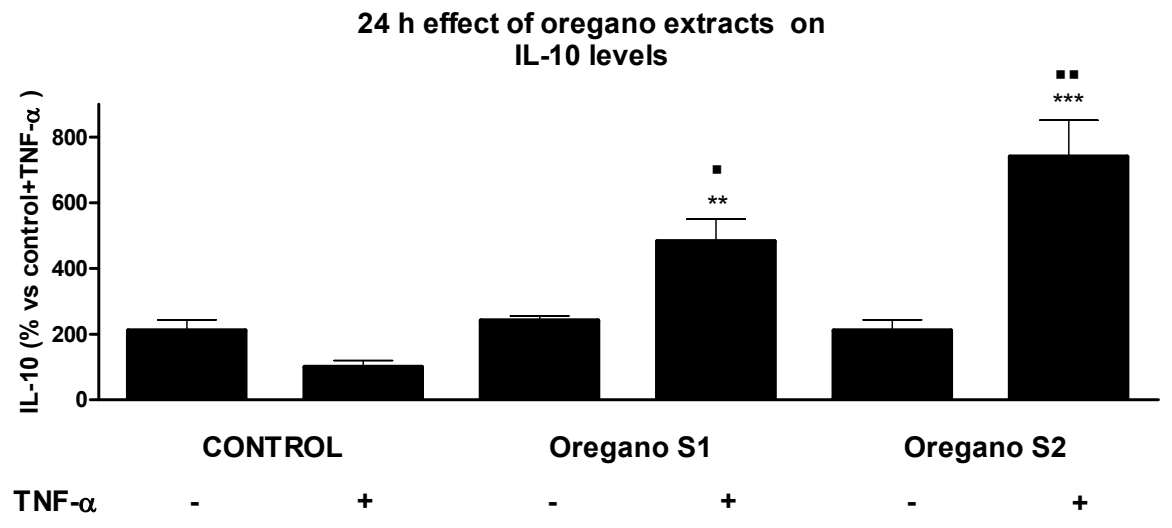

Figure 4C

Fig. 4. Effects of oregano treatment on TNF-a induced adipokine secretion by human adipocytes. The secreted interleukin-1 $\beta$ (4A), interleukin-6 (4B) and interleukin-10 (4C) into the medium were measured. Results are shown as the means \pm SEM of triplicate determinations. Statistic Dunnett's multiple comparison test VS Ctrl + TNF- $\alpha$ signification is represented by * P values less than 0.05 significant ${ }^{* *} P$ values less than 0.01 very significant and ${ }^{* * *} P$ values less than 0.001 extremely significant. Statistic "Bonferroni multiple comparison test VS Ctrl -TNF- $\alpha$ signification is represented by $\cdot P$ values less than 0.05 significant, $-\cdot P$ values less than 0.01 very significant and $\cdots$ P values less than 0.001 extremely significant. 
of $10 \mathrm{ng} / \mathrm{ml}$ for 6 hours. After that time, the induced adipocytes were treated with $30 \mu \mathrm{g} / \mathrm{ml}$ (the highest concentration of oregano which causes no cytotoxicity at 24 hours).

Incubation period of 24 hours TNF- $\alpha$ activated cells showed an increased released of IL-1 $\beta$ and IL-6 but a decreased in IL-10 respect to non-activated controls (see Figures 4A-C).

The results show a moderate decrease in pro-inflammatory adipokine synthesis (IL-1 $\beta$, IL-6) and an increase in the production of anti-inflammatory adipokine (IL-10). Oregano extract S1 and S2 decrease secretion levels of IL-1 $\beta$ in activated cells restoring or even below to the non-activated control level. Similar behavior presented oregano S1 and S2 on the IL-6 secretion levels although decreases were less singnificant. On the other hand, IL-10 levels were not affected when non activated cells were incubated with any of the fraction extracts but in the treatments in activated cells, a very significant increase of the secretion was observed ( $\mathrm{p}<0.01$ for oregano S1 and $\mathrm{p}<0.001$ for oregano S2).

\section{$24 \mathrm{~h}$ effect of oregano on mRNA levels of IL $1 \beta$}

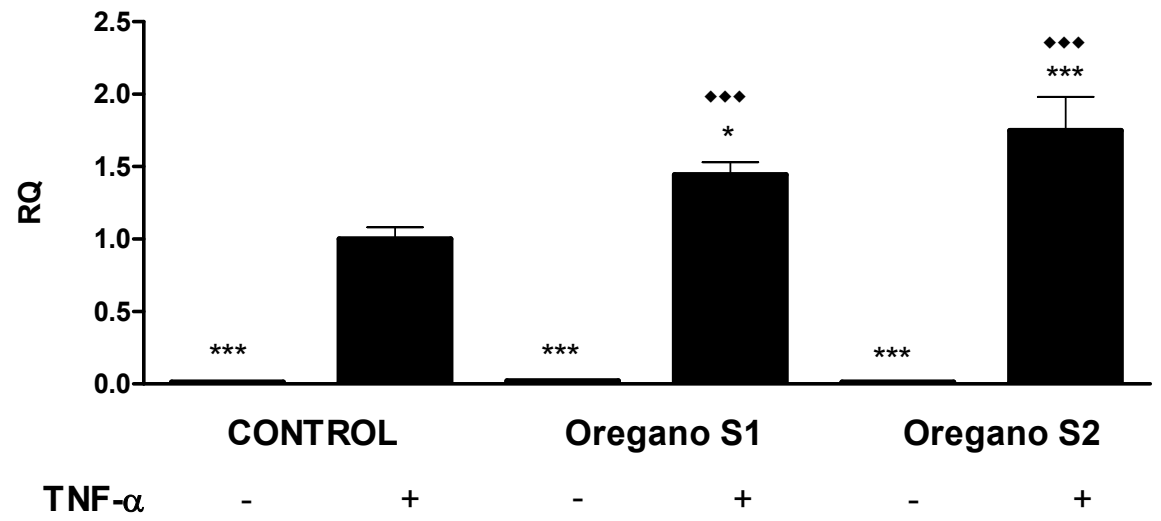

Figure 5A

\section{$24 \mathrm{~h}$ effect of oregano on mRNA levels of IL 6}

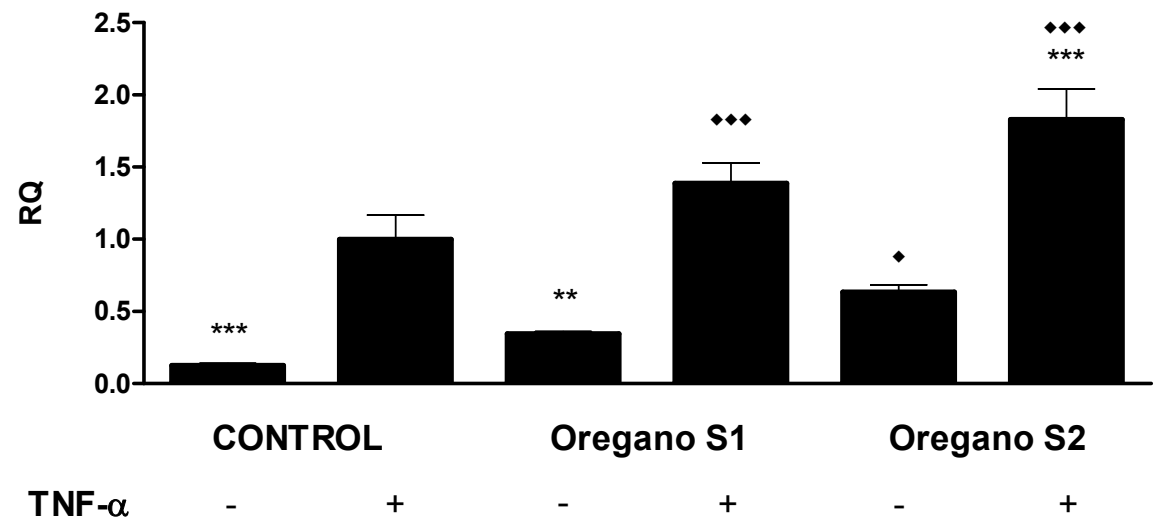

Figure 5B 


\section{$24 \mathrm{~h}$ effect of oregano on mRNA levels of IL-10}

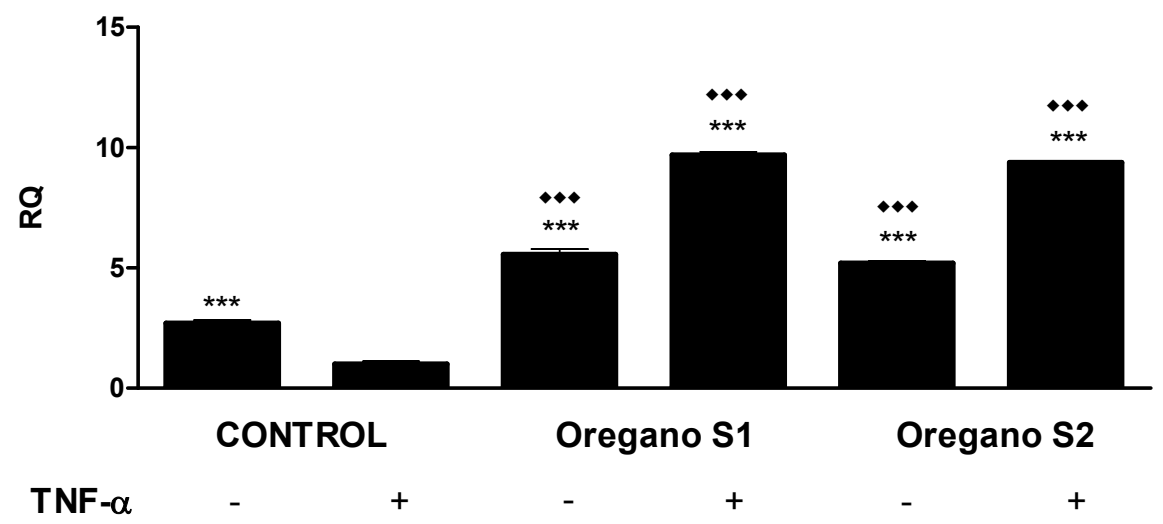

Figure 5C

Fig. 5. Effect of oregano on the relative $24 \mathrm{~h}$ transcription gene quantification (RQ) of IL-1 $\beta$ (6A) and IL-6 (6B) on human adipocytes. Cells were differentiated and treated as described in Material and Methods section. Data represent means \pm SEM calculated from six independent experiments with 3 replicates for each treatment. Statistic Dunnett's multiple comparison test VS Ctrl +oxLDL signification is represented by: * $\mathrm{P}$ values less than 0.05 (significant), ${ }^{* *} \mathrm{P}$ values less than 0.01 (very significant), and ${ }^{* * *} \mathrm{P}$ values less than 0.001 (extremely significant). Statistic Bonferroni multiple comparison test VS Ctrl - TNF-a signification is represented by: $\bullet P$ values less than 0.01 (very significant), and $\leftrightarrow$ P values less than 0.001 (extremely significant).

Unfortunately, IL-1 $\beta$ gene expression in activated cells treated with any of oregano fractions was not reverted to activated control cells. In the case of non-activated cells, treatments with either oregano fraction do not modify the transcription of IL-1 $\beta$. Regarding IL-6 gene transcription was also increased in activated cells treated for $24 \mathrm{~h}$ and a slightly modify were observed in non activated cells when treated with oregano S1 or S2. IL-10 transcription gene was enhanced at any treatment, especially when cells were activated. (Figures 5A-C)

\subsection{Effect of oregano on the TNF- $\alpha$-induced secretion of hormones and their gene expressions}

The results show a moderate decrease in pro-inflammatory leptin and an increase in the production of adiponectin anti-inflammatory secreted hormone level. Treatment with oregano extracts inhibited TNF- $\alpha$-induced increasing on the secretion of leptin and decreasing of adiponectin (Figures 6A-B).

Leptin levels, secreted by control TNF- a-induced adipocytes increased, compared to the non- activated control. Treatment with any of the SFE extracts essential oils, restored the levels to the presented in non-activated control. In not activated cells, oregano extract do not produced any significant decrease on leptin levels compared with the non-activated control (Figure 6A).

Both oregano extracts, S1 and S2, increased very significantly the adiponectin secreted levels $(\mathrm{p}<0,001)$ in activated adipocytes. In non-activated, changes on the adiponectin secretion levels had not been observed when treated with oregano S1 or S2 (see Figure 6B). 
$24 \mathrm{~h}$ effect of oregano extracts on

leptin levels

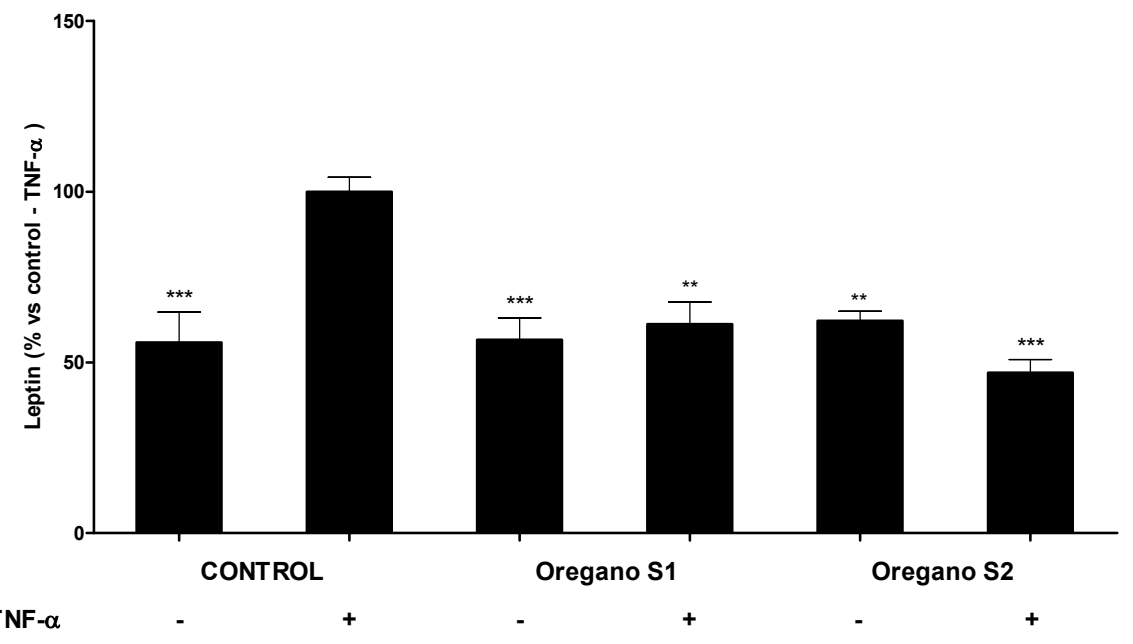

Figure 6A

$24 \mathrm{~h}$ effect of oregano extracts on adiponectin levels

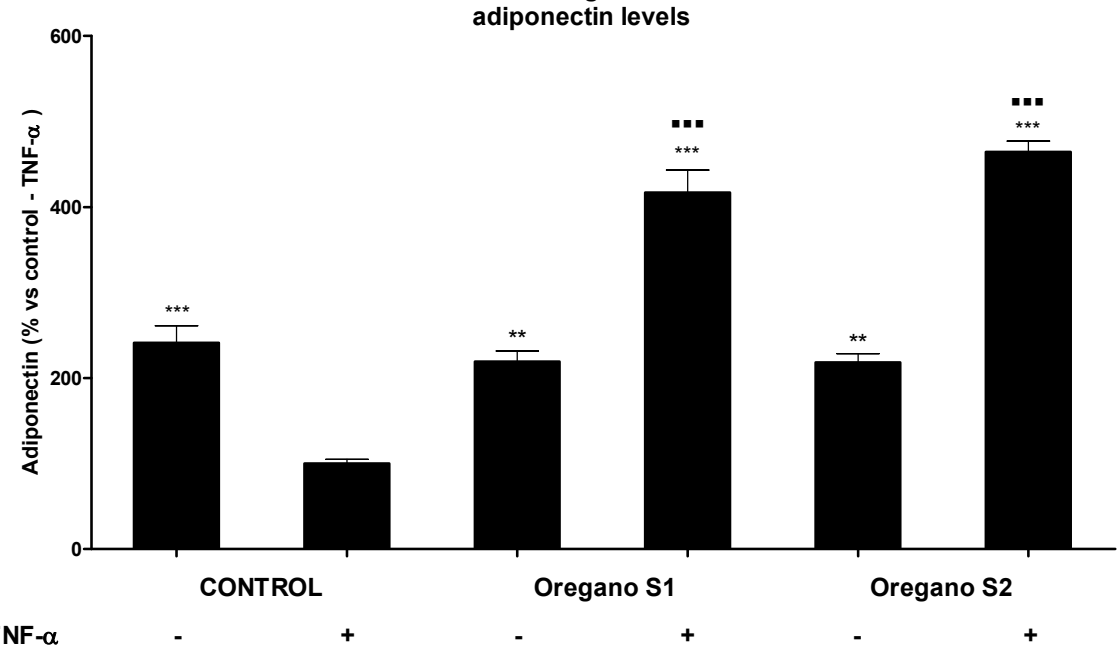

Figure 6B

Fig. 6. Effects of oregano treatment on TNF-a induced adipokine secretion by human adipocytes. The secreted adipokines leptin (5A) and adiponectin (5B) into the medium were measured. Results are shown as the means \pm SEM of triplicate determinations. Statistic Dunnett's multiple comparison test VS Ctrl +TNF-a signification is represented by * $\mathrm{P}$ values less than 0.05 significant ${ }^{* *} P$ values less than 0.01 very significant and ${ }^{* * *} P$ values less than 0.001 extremely significant. Statistic "Bonferroni multiple comparison test VS Ctrl TNF-a signification is represented by $\cdot \boldsymbol{P}$ values less than 0.05 significant, $\cdot \boldsymbol{- P}$ values less than 0.01 very significant and $\cdots P$ values less than 0.001 extremely significant. 
Transcriptions of the leptin hormone shown a general decrease in all groups when adipocytes were treated with any of the SFE essential oils. Tegarding to adiponectin, both oregano extracts, S1 and S2, increased very significantly the adiponectin gene expression in activated adipocytes but in non-activated, changes were not observed when treated with oregano S1 or S2 (Figures 7A-B).

\section{$24 \mathrm{~h}$ effect of oregano on mRNA levels of leptin}

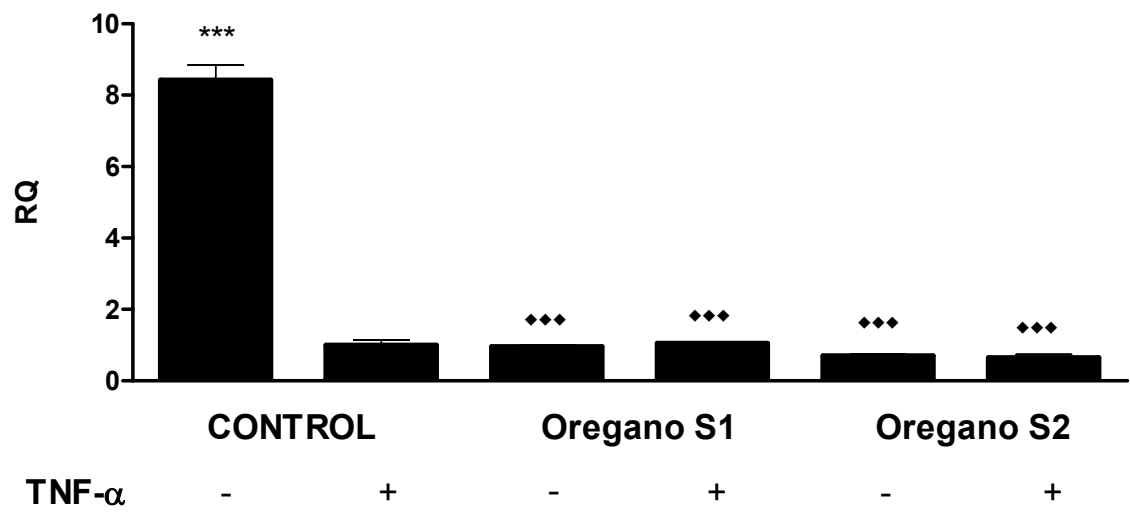

Figure 7A

$24 \mathrm{~h}$ effect of oregano on mRNA levels of adiponectin

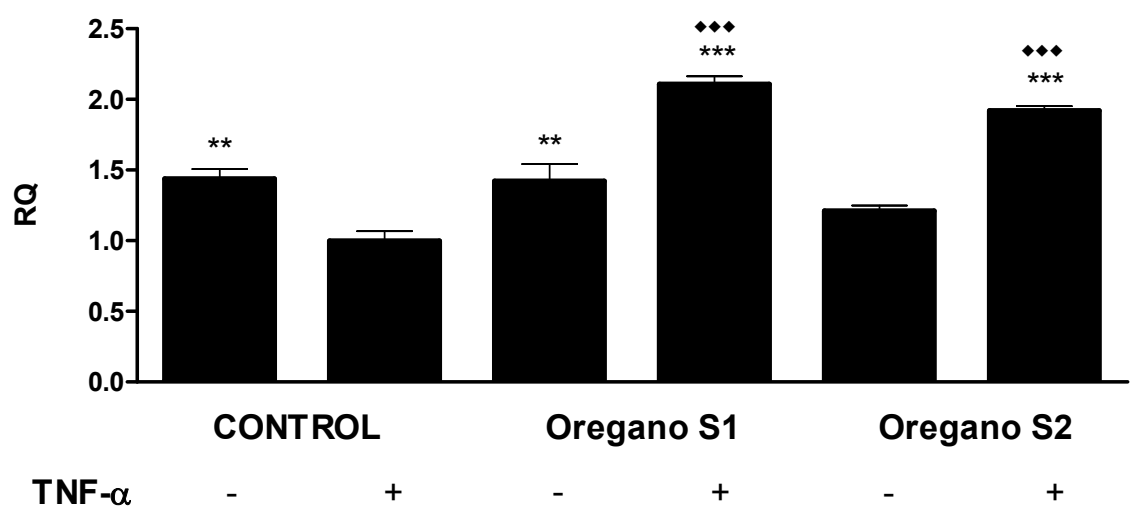

Figure 7B

Fig. 7. Effect of oregano on the relative $24 \mathrm{~h}$ transcription gene quantification (RQ) of leptin (7A) and adiponectin (7B) on human adipocytes. Cells were differentiated and treated as described in Material and Methods section. Data represent means \pm SEM calculated from six independent experiments with 3 replicates for each treatment. Statistic Dunnett's multiple comparison test VS Ctrl +oxLDL signification is represented by: * P values less than 0.05 (significant), ${ }^{* *} \mathrm{P}$ values less than 0.01 (very significant), and ${ }^{* * *} \mathrm{P}$ values less than 0.001 (extremely significant). Statistic Bonferroni multiple comparison test VS Ctrl - TNF-a signification is represented by: $\leftrightarrow P$ values less than 0.01 (very significant), and $\leftrightarrow \bullet$ values less than 0.001 (extremely significant). 


\section{Discussion}

It is described that during inflammation, the mature adipocytes are responsible for increasing production of pro-inflammatory adipokines (Ouchi et al., 2001). Infiltration of macrophages in the adipose tissue, and the consequent secretion of TNF-alpha by those, is a primary stimulus for the inflammatory properties of adipose tissue and intensify macrophage expression of TNF- $a$. This produces inflammation that if it persists provoke a chronic inflammation state (Guilherme et al., 2008).

Several natural compounds are known for their beneficial properties to some diseases or their derived complications and particularly concerning to their anti-inflammatory effects. Some of these effects include inhibition of the TNF-a signaling in adipocytes (Gonzales and orlando, 2008). Our oregano extracts as other natural compounds described, could have beneficial properties to some diseases or their derived complications and particularly concerning to their anti-inflammatory effects (Khanna et al., 2007).

In the present study, we have found that SFE oregano essentials oils inhibit TNF-a-induced increases in the secretion of pro-inflammatory adipokines (IL-1 $\beta$, IL-6 and leptin) and the TNF-a-induced decreases of IL-10 and adiponectin secretion.

Our data suggest that oregano extract recovers the TNF-a-induced increases in inflammatory adipokines. A study demonstrated that resveratrol produced similar changes in adipokine secretion (Anh et al., 2007). In a study about the treatment of colitis in mouse with thyme and oregano essential oils reduced the levels of pro-inflammatory citokines were observed when the essential oils were administrated. In addition, the mice treated with these oils recover their corporal weight after the treatment, which could suggest that the oregano could exert effects on the adipocytes (Bukovska et al., 2007).

Main compounds present in supercritical oregano extract were sabinene hydrate, thymol and carvacrol. Anti-inflammatory effect of thymol has been demonstrated in human neutrophiles incubated with 10 or $20 \mu \mathrm{g} / \mathrm{ml}$ of this compound (Braga et al., 2006). Mice edema is reported to be reduced with a topical application of $100 \mu \mathrm{g} / \mathrm{cm}^{2}$ of carvacrol (Sosa et al., 2005). Moreover, antioxidant properties of thymol and carvacrol have been demonstrated in several studies, suggesting their use as nutraceuticals ingredients in the development of novel functional foods. Derivatives of thymol and carvacrol have been described as antioxidant according to the DPPH radical scavenging method (Mastelic et al., 2008). Essential oils of oregano and their components carvacrol and thymol inhibited 3-nitrotyrosine formation, biomarker of the oxidative stress, supporting the nutraceutical value of oregano and the potential of thymol and carvacrol in preventing the formation of toxic products by the action of reactive nitrogen species (Prieto et el., 2007). Recently, carvacrol has been identify as responsible of COX-2 expression and as an activator of PPAR alpha and gamma provoking a PPARgammadependent suppression of COX-2 promoter activity as well, in human macrophage-like U937 cells (Hotta et al., 2010). In addition, carvacrol suppressed lipopolysaccharide-induced COX-2 mRNA and protein expression, suggesting that carvacrol regulates COX-2 expression through its agonistic effect on PPARgamma. Thymol and carvacrol prevented autoxidation of lipids (Yanishlieva et al., 1999).

Although beneficial effect of sabinene in inflammation was previously known, molecular keys in anti-inflammatory or antioxidant effects of sabinene hydrate have been recently described: Effects of sabinene (1\%) from Chinese herbs on ocular inflammation have been described (Yao and Chiou, 1993). In that study was found that lens protein-induced inflammation was inhibited significantly by the topical instillation of sabinene (1\%). And 
Cryptomeria japonica essential oil containing kaurene (17.20\%), elemol (10.88\%), gammaeudesmol $(9.41 \%)$, and sabinene $(8.86 \%)$ as the major components inhibits the growth of drug-resistant skin pathogens and LPS-induced nitric oxide and pro-inflammatory cytokine production (nitric oxide (NO), prostaglandin E2 (PGE2), tumor necrosis factor (TNF)-alpha, interleukin (IL)-1beta, and IL-6 production in lipopolysaccharide (LPS)-activated RAW 264.7 macrophages (Yoon et al., 2009).

Our group recently has described similar anti-inflammatory effects from supercritical extract of origanum on activated human THP-1 macrophages cells. The results showed a decrease in the pro-inflammatory TNF- $\alpha$, IL-1 $\beta$ and IL- 6 cytokines synthesis as well as an increase in the production and mRNA expressions of the anti-inflammatory cytokine IL-10 (Ocaña-Fuentes et al., 2010).

For future works, it is necessary to determinate the mRNA expression levels of others adipokines and their mRNA levels of the implicated transcriptions factors that regulate the adipokine synthesis such as PPARY and NF-k $\beta$, transcription factor that all of the inflammatory mediators linked to chronic inflammation have been shown to be regulated (Anh et al., 2007). Also the activity of enzymes related to the inflammatory process such as COX-2 and iNOS will be the subject of our future investigations.

In summary, $\mathrm{CO}_{2}$ supercritical oregano extracts showed anti-inflammatory properties in a cellular model of inflammation and could have a play on the energy homeostasis through regulation of related hormone level by: Decreasing pro-inflammatory adipokines and increasing the anti-inflammatory IL-10, decreasing leptin, increasing adiponectin release and modifying their mRNA expressions. These results could help in suggest that essential oils from oregano could be used in future as novel options for treatment of chronic diseases based on inflammatory processes, as for example, including in novel foods. Although more studies as said above are needed.

\section{References}

Ahn, J., H. Lee, S. Kim, and T. Ha, Resveratrol inhibits TNF-alpha-induced changes of adipokines in 3T3-L1 adipocytes. Biochem. Bioph. Res. Co., 2007. 364(4): p. 972-977.

Almeida, P., Ferreira, S., Crossover pressure for SFE of spearmint (Mentha spicata L.) essential oil with pure $\mathrm{CO} 2$ and with $\mathrm{CO} 2$ plus ethanol. I Iberoamerican Conference on Supercritical Fluids. Prosciba Book of Abstracts, 2007.: p. 31.

Bastard, J.-P., M. Maachi, C. Lagathu, M.J. Kim, M. Caron, H. Vidal, J. Capeau, and B. Feve, Recent advances in the relationship between obesity, inflammation, and insulin resistance. Eur. Cytokine Netw., 2006. 17(1): p. 4-12.

Braga, P.C., M. Dal Sasso, M. Culici, T. Bianchi, L. Bordoni, and L. Marabini, Antiinflammatory activity of thymol: inhibitory effect on the release of human neutrophil elastase. Pharmacology, 2006. 77(3): p. 130-136.

Bukovska, A., S. Cikos, S. Juhas, G. Il'kova, P. Rehak, and J. Koppel, Effects of a combination of thyme and oregano essential oils on TNBS-induced colitis in mice. Mediat. Inflamm, 2007. 2007: p. 23296.

Chun, S., D.A. Vattem, Y.T. Lin, and K. Shetty, Phenolic antioxidants from clonal oregano (Origanum vulgare) with antimicrobial activity against Helicobacter pylori. Process Biochem., 2005. 40(2): p. 809-816.

Desruisseaux, M.S., Nagajyothi, M.E. Trujillo, H.B. Tanowitz, and P.E. Scherer, Adipocyte, adipose tissue, and infectious disease. Infect. Immun, 2007. 75(3): p. 1066-1078. 
Gonzales, A.M. and R.A. Orlando, Curcumin and resveratrol inhibit nuclear factor-kappaBmediated cytokine expression in adipocytes. Nutr. Metab., 2008. 5(1): p. 17.

Guilherme, A., J.V. Virbasius, V. Puri, and M.P. Czech, Adipocyte dysfunctions linking obesity to insulin resistance and type 2 diabetes. Nat. Rev. Mol. Cell Biol., 2008. 9(5): p. 367-377.

Hotta, M., R. Nakata, M. Katsukawa, K. Hori, S. Takahashi, and H. Inoue, Carvacrol, a component of thyme oil, activates PPARalpha and gamma and suppresses COX-2 expression. J. Lipid Res., 2010. 51(1): p. 132-139.

Juhás, S., S. Cikos, S. Czikková, J. Veselá, G. Il'ková, T. Hájek, K. Domaracká, M. Domaracký, D. Bujnáková, P. Rehák, and J. Koppel, Effects of borneol and thymoquinone on TNBS-induced colitis in mice. Folia Biol, 2008. 54(1): p. 1-7.

Khanna, D., G. Sethi, K.S. Ahn, M.K. Pandey, A.B. Kunnumakkara, B. Sung, A. Aggarwal, and B.B. Aggarwal, Natural products as a gold mine for arthritis treatment. Curr. Opin. Pharmacol., 2007. 7(3): p. 344-351.

Mastelic, J., I. Jerkovic, I. Blazevic, M. Poljak-Blazi, S. Borovic, I. Ivancic-Bace, V. Smrecki, N. Zarkovi'c, K. Brcic-Kostic, D.z. Vikic-Topic, and N. Müller, Comparative Study on the Antioxidant and Biological Activities of Carvacrol, Thymol, and Eugenol Derivatives. J. Agric. Food Chem,, 2008. 56(11): p. 3989-3996.

Mukhopadhyay, M., in Natural extracts using supercritical carbon dioxide, M. Mukhopadyay, Editor. 2000, CRC Press, Boca Ratón, FL: USA. p. 3.

Ocaña-Fuentes A, Arranz-Gutiérrez E, Señorans FJ, Reglero G. Supercritical fluid extraction of oregano (Origanum vulgare) essentials oils: anti-inflammatory properties based on cytokine response on THP-1 macrophages. Food Chem Toxicol. 2010 Jun;48(6):1568-75.

Ouchi, N., S. Kihara, T. Funahashi, Y. Matsuzawa, and K. Walsh, Obesity, adiponectin and vascular inflammatory disease. Curr. Opin. Lipidol., 2003. 14(6): p. 561-566.

Ouchi, N., S. Kihara, Y. Arita, M. Nishida, A. Matsuyama, Y. Okamoto, M. Ishigami, H. Kuriyama, K. Kishida, H. Nishizawa, K. Hotta, M. Muraguchi, Y. Ohmoto, S. Yamashita, T. Funahashi, and Y. Matsuzawa, Adipocyte-derived plasma protein, adiponectin, suppresses lipid accumulation and class A scavenger receptor expression in human monocyte-derived macrophages. Circulation, 2001. 103(8): p. 1057-1063.

Prieto, J.M., P. Iacopini, P. Cioni, and S. Chericoni, In vitro activity of the essential oils of Origanum vulgare, Satureja montana and their main constituents in. Food Chem., 2007. 104(3): p. 889-895.

Rajala, M.W. and P.E. Scherer, Minireview: The adipocyte--at the crossroads of energy homeostasis, inflammation, and atherosclerosis. Endocrinology, 2003. 144(9): p. 3765-3773.

Rodríguez-Meizoso, I., F.R. Marin, M. Herrero, F.J. Señorans, G. Reglero, A. Cifuentes, and E. Ibáñez, Subcritical water extraction of nutraceuticals with antioxidant activity from oregano. Chemical and functional characterization. J. Pharmaceut. Biomed., 2006. 41(5): p. 1560-1565.

Simons, P.J., P.S. van den Pangaart, C.P.A.A. van Roomen, J.M.F.G. Aerts, and L. Boon, Cytokine-mediated modulation of leptin and adiponectin secretion during in vitro adipogenesis: evidence that tumor necrosis factor-alpha- and interleukin-1betatreated human preadipocytes are potent leptin producers. Cytokine, 2005. 32(2): p. 94-103. 
Sosa, S., G. Altinier, M. Politi, A. Braca, I. Morelli, and R. Della Loggia, Extracts and constituents of Lavandula multifida with topical anti-inflammatory activity. Phytomedicine, 2005. 12(4): p. 271-277.

Trayhurn, P. and I.S. Wood, Signalling role of adipose tissue: adipokines and inflammation in obesity. Biochem. Soc. T., 2005. 33(Pt 5): p. 1078-1081.

$\mathrm{Wu}, \mathrm{Z} . \mathrm{h}$. and S.-p. Zhao, Adipocyte: a potential target for the treatment of atherosclerosis. Med. Hypotheses, 2006. 67(1): p. 82-86.

Yanishlieva, N.V., E.M. Marinova, M.H. Gordon, and V.G. Raneva, Antioxidant activity and mechanism of action of thymol and carvacrol in two lipid systems. Food Chem., 1999. 64(1): p. 59-66.

Yao, Q.S. and G.C. Chiou, Inhibition of crystallins-induced inflammation in rabbit eyes with five phytogenic compounds. Acta Pharm. Sinic., 1993. 14(1): p. 13-17.

Yoon, W.-J., S.-S. Kim, T.-H. Oh, N.H. Lee, and C.-G. Hyun, Cryptomeria japonica essential oil inhibits the growth of drug-resistant skin pathogens and LPS-induced nitric oxide and pro-inflammatory cytokine production. Pol. J. Microbiol., 2009. 58(1): p. 61-68.

Youdim, K.A. and S.G. Deans, Effect of thyme oil and thymol dietary supplementation on the antioxidant status and fatty acid composition of the ageing rat brain. Brit. J Nutr, 2000. 83(1): p. 87-93. 


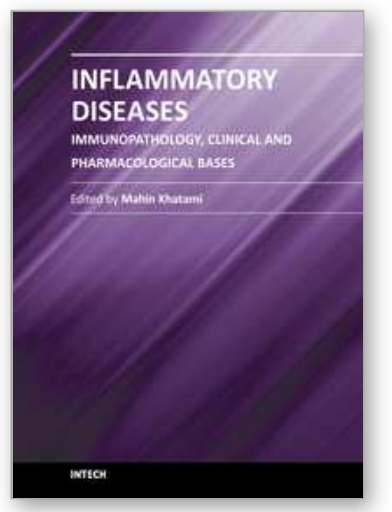

\author{
Inflammatory Diseases - Immunopathology, Clinical and \\ Pharmacological Bases \\ Edited by Dr Mahin Khatami
}

ISBN 978-953-307-911-0

Hard cover, 396 pages

Publisher InTech

Published online 10, February, 2012

Published in print edition February, 2012

This book is a collection of comprehensive reviews contributed by experts in the diverse fields of acute and chronic inflammatory diseases, with emphasis on current pharmacological and diagnostic options. Interested professionals are also encouraged to review the contributions made by experts in a second related book entitled "Inflammation, Chronic Diseases and Cancer"; it deals with immunobiology, clinical reviews, and perspectives of the mechanisms of immune inflammatory responses that are involved in alterations of immune dynamics during the genesis, progression and manifestation of a number of inflammatory diseases and cancers, as well as perspectives for diagnosis, and treatment or prevention of these disabling and potentially preventable diseases, particularly for the growing population of older adults around the globe.

\title{
How to reference
}

In order to correctly reference this scholarly work, feel free to copy and paste the following:

A. Ocaña-Fuentes (2012). Supercritical Fluid Extraction of Oregano (Origanum vulgare) Essentials Oils Show some In Vitro Anti-Inflammatory Effects Based on Modifying Adipokine Secretion and Gene Expression on TNF-a-Induced Adipocytes, Inflammatory Diseases - Immunopathology, Clinical and Pharmacological Bases, Dr Mahin Khatami (Ed.), ISBN: 978-953-307-911-0, InTech, Available from:

http://www.intechopen.com/books/inflammatory-diseases-immunopathology-clinical-and-pharmacologicalbases/supercritical-fluid-extraction-of-oregano-origanum-vulgare-essentials-oils-show-some-in-vitro-anti-i

\section{INTECH}

open science | open minds

\section{InTech Europe}

University Campus STeP Ri

Slavka Krautzeka 83/A

51000 Rijeka, Croatia

Phone: +385 (51) 770447

Fax: +385 (51) 686166

www.intechopen.com

\section{InTech China}

Unit 405, Office Block, Hotel Equatorial Shanghai

No.65, Yan An Road (West), Shanghai, 200040, China

中国上海市延安西路65号上海国际贵都大饭店办公楼 405 单元

Phone: +86-21-62489820

Fax: $+86-21-62489821$ 
(C) 2012 The Author(s). Licensee IntechOpen. This is an open access article distributed under the terms of the Creative Commons Attribution 3.0 License, which permits unrestricted use, distribution, and reproduction in any medium, provided the original work is properly cited. 